\title{
The Militant Go-between: Émile Pouget's Transnational Propaganda (1880-1914)
}

\author{
Constance Bantman \\ Imperial College London/ Paris 13 University, UK and France
}

\begin{abstract}
This article is a study of the transnational activism of the French anarchist militant Emile Pouget (1860-1931), from his early days in the 1880s as an agitator and as the editor of the scathing anarchist weekly Père Peinard, through to his key role in the spread of revolutionary syndicalism in France and beyond. Against dominant representations focusing on his substantial journalistic and organizational propaganda exclusively within national boundaries, it suggests that Pouget did start off as a locally-minded militant in the 1880s, but later became aware of the great importance of international organization. This contribution depicts Pouget's year of exile in Britain (1894-1895) as the turning point leading to a greater international emphasis in his activism. Through Pouget, the usually unheeded transnational ramifications of belle-époque anarchism and syndicalism are highlighted, as well as the relevance of militant biography for the study of transnational networks and ideological dissemination.
\end{abstract}

keywords Emile Pouget, Anarchism, Syndicalism, Internationalism, Transnationalism, Ideology

\section{Introduction}

Émile Pouget (1860-1931) is one of the best-known anarchists of the 'heroic period' of French anarchism, between 1880 and 1914. Born in Aveyron, into a middleclass family connected with Republican and left-wing militancy, Pouget's own career as an activist began in the late 1870s, when he organized the shop assistants' trade union in Paris and started a trade newspaper. Within a few years, he became one of the prominent figures of the budding anarchist movement. In 1883, with the Communard-turned-anarchist Louise Michel, he led a hunger demonstration in Paris, during which the emblematic anarchist black flag was waved for the first time. After a stay in jail, in 1889, Pouget launched Le Père Peinard, which soon became one of the most iconic French anarchist papers, famous above all for its biting slang and aggressive working-class stance, but also for its influence over the course of the labour movement in France and abroad. Pouget was later known as one of the earliest propagandists of anarcho-syndicalism in France, and one of the co-drafters of the 1906 Charte d'Amiens, the manifesto of the French revolutionary syndicalist movement, which immediately gained great international influence, inspiring a number of similar movements across the world. In the British context, the union organizer Tom Mann derived inspiration from the French CGT in his endeavour to radicalize British unions. Recent research has also brought to light the impact of the Charte in Portugal or Argentina.1

Unsurprisingly, Pouget's fascinating personality and militant career have attracted the interest of several biographers, but some aspects of his multi-faceted activism remain unexplored. 2 This is especially true of his international militancy. As his latest biographer, Xose Ulla Quiben points out, 'for some, he was the jubilant militant, who ignored the more austere side of militancy [. . .] For others, he was the champion of revolutionary syndicalism, of a fighting syndicalism'.3 The first image seems to have been the most enduring, as Pouget remains remembered above all - 
and well beyond anarchist circles - as the editor of the Père Peinard, one of the most memorable incarnations of the anarchist of the Belle Époque, with his mocking defiance of all he powers that be and his attachment to the Paris craft culture and the French evolutionary tradition. Only in more restricted militant or academic groups is Pouget dentified with his great ideological and militant legacy, as one of the early champions f revolutionary syndicalism.

This contribution focuses on a third facet of Pouget - Pouget as an internationalist militant, who spent a year exiled in Britain at the peak of anti-anarchist repression in the 1890s, and became an active internationalist from then on, playing an important role in the development of revolutionary syndicalism in France and abroad, as well as in the coordination of the international syndicalist movement and the organization of international protest campaigns. In the wake of Jean Maitron's statement, it is usually taken for granted that Pouget became truly interested in trade unions during his stay in Britain,4 thereafter becoming one of the leading exponents of anarcho-syndicalism; however, little attention has been paid to the detail of his years in exile and the subsequent progression of his international militant career. This has resulted in obscuring not only the international and transnational dimensions of Pouget's impact, but also interpretations of fin-de-siècle French anarchism in general.

Through the case of Pouget, three main themes can be investigated: first, it makes it possible to emphasize the status of anarchism as an internationalist and transnational movement. This is especially important in France, where anarchism has often been studied in isolation - probably because of a somewhat French-centred outlook, in which France's status as the 'cradle of the revolution' and the strong local ties of anarchism prevented paying attention to the vital connections with foreign movements. Anarchism and, more generally, labour history have been embedded in a national - even a nationalistic - historiography which has led to a disdain of the international and transnational connections of French labour history. 5 The centrality of transnational developments has started to be reassessed in most national historiographies of anarchism, either through overviews of each national movement's broader context 6 studies of exile colonies 7 or biographies of transnational activists. 8

Such a rewriting is essential for French anarchism in order to avoid hegemonic narratives which obliterate the international influences and ramifications which have shaped the movement's history. Secondly, the case of Pouget provides an insight into the internationalism of those revolutionaries excluded from the Second International and the conditions of their accession to international militancy. Indeed, Pouget is typical of a transitional generation in terms of international militancy, between the pioneers of the First International and the very savvy internationalists who occupied the front stage from the years just preceding the war, such as Tom Mann or Alfred Rosmer, who developed fully some of his ideas.9 Through his emphasis on internationalism as an ideal but also a practical organizational task, he can be said to bridge the gap between the groundbreaking generation of the First International, where internationalism was 'rather vague [. . .] premised as much on delight in travel and "foreigner" as on any explicit sense of international solidarity',10 and the early twentieth century, when labour conflicts came to be consciously fought on an international scale.

With a view to transnational methodology, Pouget's militant itinerary highlights the importance of certain key actors - men (and, more rarely, women) bringing together several networks and thus acting as go-betweens pivotal to an effective transnationalism. Despite the recent transnational turn in history, the figure of the gobetween still needs to be investigated.11 In general terms, transnational history can be referred to as the study of 'the entangled nature of the different national and local histories [. . .] [of] people, ideas, products, processes and patterns that operate over, across, through, beyond, above, under, or in-between polities and societies'.12 In the 
field of labour history, transnational history encompasses the study of the globalization of labour and capital as well as the formation - or not - of an interconnected labour movement, which is both institutional and informal. One of the merits of biography is to bind together these various levels, especially by highlighting the connections between the local, the national and the international, as well as institutional and extra-institutional levels. Pouget's own career is exemplary in this respect.

In many cases, transnational exchanges and transfers have resulted from the migration of a significant number of actors; for instance, Marcel van der Linden has stressed the role of work migrations as a vector for ideological transfers and the functioning of transnational movements.13 However, in other cases, networks and ideological transfers have been engineered almost single-handedly, and the modalities of intervention of the international militants who carried them out are still to be analyzed. In the field of anarchism and syndicalism, important actors in this respect would include Peter Kropotkin, Errico Malatesta, Ferdinand Domela Nieuwenhuis, or Christian Cornelissen.14 This approach is especially relevant in the broad period of the First and Second Internationals, when such charismatic ideologues and organizers played a key role in the international labour movement.15

Two main questionings can inform such an enquiry: how does one become a transnationalist, and which influences may either thwart or determine such a political commitment? Secondly, against the assumption that the go-between can be a mere vessel for ideas, the question of how his own interests and background contributed to define and reshape the ideas he imported or exported must be considered. Pouget's case in this light is especially interesting, since he does not belong to the canon of activists usually considered from this transnational perspective, and appears as one of the essential yet usually unnoticed intermediaries in the making of transnational militancy. Moreover, his example emphasizes several points which may be observed in other individual journeys: the limited impact of working-class xenophobia in 1880s' France on the development of elite internationalism, the changing nature of internationalism in the 1890s, with a growing awareness of the necessity of building an international labour movement in the decades just before the First World War, and the role of exile as a rite of passage experienced by most transnationalists in socialist politics during this period.

\section{Early biographical sketch - a limited internationalism}

In the late 1870 s and early 1880s, after he moved to Paris, Pouget's early militancy was almost exclusively oriented towards the French labour movement. He was active on three main fronts: trade unionism, anarchist agitation, and journalism. In these years, trade unionism was only just being reborn, after the very quiet decade which had followed the repression of the 1871 Paris Commune. Trade unions remained illegal until 1884, and were barely a national reality in France, so that international activism in this field was a distant prospect. As far as Pouget's militant sociability was concerned, he was not very close to the exile groups present in Paris at the time. The two main anarchist circles he regularly visited in those years Gustave Rousseau's wine shop on the rue St-Martin and the Cercle Anarchiste International de Paris 16 - were predominantly French, and mainly concerned with French events, such as the connection between anarchists and trade unions in France.17 And yet, in the early 1880s, there were a number of prominent activists in the capital, including Malatesta and occasionally Kropotkin.18

These exiles regularly attended and spoke at the main revolutionary socialist circle of Paris, the Cercle de la rue Pascal, near the Pantheon. This informal group was also frequented by another young anarchist convert, Jean Grave. Just like Pouget, by the late 1880s, Grave had become a prominent anarchist activist and journalist. He was also a very active, but unacknowledged, transnational actor: as 
early as 1885, Grave was pivotal in disseminating Kropotkin's ideas on anarchist communism and his strategic reflection in Le Révolté, a high-brow paper initially founded by Kropotkin and Élisée Reclus 19 and then taken over by Grave. After Kropotkin settled down in London, in 1886, Grave also kept him informed of developments in the French anarchist movement and, more generally, did much to coordinate anarchist movements across the world. Just like Pouget, Grave's importance as an international go-between remains largely unheeded and is worth noting: both are usually depicted as leading militants of pre-WW1 French anarchism, with very few acknowledgements of the international influences they both received and exerted. However, equally significant is the fact that Pouget's and Grave's transnational activisms, although they functioned in both cases through informal networks and friendships, differed largely in their styles and were based on different themes. Their differing starting points adumbrate these contrasts, as Grave soon became involved in international networks, and became the direct heir of the ideals of the First International through Kropotkin, while Pouget was initially more concerned with national developments.

At this early stage, it was in his journalistic writings that Pouget's internationalist concerns appeared most clearly, although there again, national and local news remained in the foreground, along with more theoretical or historical pieces. Most issues of the Père Peinard until about 1890 dealt with the history of socialism in France, virulently attacking Pouget's hate figures or exploring the many facets of the workers' plight. However, Pouget occasionally made internationalist professions of faith, calling for the day when 'the workers of all countries - Germans, Italians, Spaniards, Austrians, Frenchmen and all the others will take one another's hand and all dance together to the sound of a crazy Carmagnole'.20 On a more practical level, Pouget also kept his readers informed of the developments in the labour movements of foreign countries, a novel practise for anarchists at the time, although not for the rest of the socialist movement.21 Anti-colonialism and antiimperialism were also recurring themes in the pages of the Père Peinard 22 where attacks on France's colonial rule or British violence in India were numerous, along with a general denunciation of the greed underpinning all colonial ventures:

\footnotetext{
India used to be a beautiful land: there were plentiful crops and culture was done nicely; without being happy, workers over there were not as hard-up as in Europe. Since the English invaded the country, all that has changed, for god's sake! They have destroyed everything, the brutes [. . .] If [Indians] happen to complain, the English just answer: 'What then? We are coming to civilise you, and you're not happy!'23
}

Predictably, he was especially critical of the British Royal family, who epitomized the injustice and arbitrariness of the country's social inequalities:

\footnotetext{
'That old drunk Victoria should hurry up and die in her royal sack [. . . ] if she can only count on her little soldiers to defend her against the prols, she may have to buy a ticket to visit the stars'.24
}

In other respects, however, Pouget's rhetoric relied on national stereotyping calling the Italians 'les Macaronis', deriding the 'Angliches' with their 'wishy-washy airs',25 for instance - although this was probably a catchy rhetoric for his workingclass audience, and was also consistent with the paper's general tone. Much has also been written about Pouget's tardiness in joining the Dreyfusard camp when the Dreyfus Affair tore France in two.26 Indeed, in the 1899, when L'Affaire broke out, after the anarchist journalist Bernard Lazare came out in defence of Dreyfus, few other anarchists stood up in sympathy with the convicted captain. Pouget was even scathing in proclaiming his lack of interest in the plight of yet another capitalist, suggesting possible anti-Semitic or nationalist tendencies - which in any event proved short-lived. Even his cutting attacks on Rothschild and depiction of Dreyfus as 
a greedy Jew were based on the then-widespread castigation of Jews as the embodiment of the evils of capitalism and should be put in perspective.27 However, such ambiguous positions may have led to the depiction of Pouget as a militant little concerned with international affairs and cosmopolitanism.

Indeed, Pouget's predominantly verbal and intellectual internationalism was above all reminiscent of the time of the foundation of the First International, when 'the internationalism of [. . . ] organisations was essentially theoretical, or perhaps rather ideological, in nature, and in practise, it was expressed above all in protestations of solidarity and demonstrations in support of the "brethren" in other countries, or of nationalities engaged in the struggle for independence'.28 But even if Pouget's internationalist declarations were rather rare and theoretical, they remained fairly exceptional at a time when France was experiencing a tidal wave of working-class xenophobia, when mass demonstrations against foreigners and daily hostilities were the norm.29 It was all the more striking as Pouget also explicitly opposed such xenophobic outbursts.30 It confirms that, at the time, anarchists were in a more propitious position to become internationalists, as this working-class xenophobia was tied in with the Republican and national sentiment, which the anarchists of course rejected.31

A final caveat is also that internationalism seems to have been an elite concern within the anarchist movement, and that Pouget's positions, like those of other anarchist organizers were more open-minded, in comparison with the interests of the average anarchist militant. For instance, a Paris police spy once reported that the anarchist speaker Joseph Tortelier had tried to discuss foreign developments during a meeting, only to be told by the listeners to focus on France.32 Moreover, while the most stable and most widely-read anarchist papers like the Père peinard and Grave's La Révolte (Le Révolté's new name after 1887) usually took into account international developments, these were barely ever mentioned in the overwhelming majority of the French anarchist press, which was very localist and precarious.

A key development occurred in the early 1890s, when a wave of anarchistinspired terrorist attacks hit France. It was followed by a fierce repression, which forced many militants to leave the country. The successive editors of the Père peinard had been subjected to legal harassment since the late $1880 \mathrm{~s}$, being arrested and heavily fi ned in turn. In February 1894, Pouget was of course one of those indicted in the Procès des Trente, the mass trial aimed at silencing anarchism once and for all. However, unlike most of them, Pouget decided to run away from France: it seems that he initially fled to Algiers, where he was involved with the local labour exchange (Bourse du travail), and eventually sought shelter in Britain, where he was condemned in abstentia.33

\section{London and the shift to transnational militancy}

Pouget's forced exile acted as an essential factor in the development of his internationalism. More specifically, there was a shift in his political activity, from international to transnational militancy, in the sense that he started describing foreign developments as an example to emulate. He frequented international militants and actively worked for the importation of foreign - and especially British - strategies into France, thus becoming an actor in ideological and militant transfers, and especially in the sphere of revolutionary syndicalism.

In the early 1890s, as anarchist-inspired terrorism led most Western European countries to close their borders to anarchist and political exiles in general, Britain remained comparatively open and thus became the main refuge for political radicals. In the capital's very international exile circles, the most prominent anarchist militants and theorists of the time could exchange ideas and tactics. After the quiet 
years of the early 1880s' Socialist Revival, Britain offered a very fertile ground for new and radical political ideas. Between 1886 and 1890, the social unrest which shook the country caught the attention of international commentators, and spurred the anarchist reflection on the opportunity of permeating trade unions as part of a broader strategy to get in touch with the workers. There had been articles on the topic in the French, Italian, and British anarchist press since the mid-1880s, but the example of Britain, especially through the Dockers' strike, was seen as a practical illustration of the potential of the general strike and efficient mass action.34 Around 1890 , Pouget was still very wary of trade unions, which he usually described as antirevolutionary groups of self-seekers; however, he followed the London events with great attention in the pages of the Peinard. Far from embracing unionism at that stage however, he concluded that 'English workers rely too much on their associations. They may have thousands of members but nothing will ever replace initiative and courage'.35Nonetheless, this was the first step of Pouget's tactical reinvention, which advocated the propagation of revolutionary ideology among the workers with a view to the general strike, against the individualist and terrorist watchwords which had prevailed in French anarchism throughout the 1880s. And as Britain, the world's most industrialized and proletarian nation, led the way in this respect, it became the main axis of Pouget's transnational propaganda.

Little is known about Pouget's life whilst in London and his networks there. He stayed in Islington, far from Soho and Fitzrovia's Petite France, where most of the exiles chose to live, under the close watch of a multitude of more or less discreet spies. Archives documenting the London years of the French anarchists thus barely mention him, even though he was one of the most politically active exiles. He was in London with his partner Marie and spent time with the militants Malatesta, Augustin Hamon, Charles Malato, Zo d'Axa - elitist circles of internationalized anarchist journalists, organizers, and activists.36 He also frequented British militants, especially the British- Italian circles around the anarchist-turned-anarcho-syndicalist paper The Torch, to which he contributed on several occasions.37 This paper was pivotal to the diffusion of early anarcho-syndicalist ideas, from June 1893 onwards, under the influence of the British anarcho-syndicalist Charles Mowbray and the Italians Saverio Merlino and Malatesta, who had been proponents of association against anarchist individualism since the mid-1880s.38

The Torch group was one of the channels through which Pouget came to refine his positions on these questions. It seems that Pouget lived for some time with Antonio Agresti, an Italian anarchist who later married Olive Rossetti, one of the young girls who edited the paper, and who was one of the first proponents of sabotage as a revolutionary strategy in the London circles.39 Pouget also contributed to the paper on several occasions. In September 1894, he launched a 'Série londonienne' of the Père peinard, which lasted for six months. Unsurprisingly, the first issue dealt almost exclusively with French politics (the peasants in political life, the assassination of President Carnot); there was a brief note announcing 'we are in London [. . . ] a city which is not funny and where watering holes are far and few'.40 Correspondence notes indicated that the paper had a widespread readership and was distributed in Geneva, Tacoma, Paterson, St Louis, Alexandria, Leeds, and Northampton; so, while the tone of the paper remained fairly insular, its large readership made it de facto a vessel for international ideological dissemination. This issue also marked a clear change, as Pouget famously pointed out to the usefulness of trade unions in the labour struggle: 'The big bosses would look really stupid if the anarchists, who they think they have gagged for good, used the opportunity to quietly infiltrate trade unions and spread their ideas there, without making any noises or a big hoo-ha'.41 In the following issue, he quoted the example of London shops, where employees had obtained weekly time off by fighting their employers without the mediation of the State: 'In London, since last year, shops have started closing on Thursday afternoons. In order to obtain this, employees have dealt directly with their 
bosses, not the State. And this is why they have succeeded'.42 This was the first of many articles in which Pouget would be drawing attention to the lessons to be learnt from the British labour movement. Such British successes in obtaining reductions of working hours would lead the CGT to call for la semaine anglaise in the 1900s. In a context of heavy anti-anarchist repression, trade unionism had the advantage of being legal. It also provided a place for anarchists to get back into concrete contact with the workers, who had been thoroughly alienated by their advocacy of terrorism. Moreover, while Pouget was in Britain, and the French anarchist movement reduced to forced inactivity, the French trade unions were appearing as increasingly receptive to libertarian ideas: in 1894, the Nantes Congress of French trade unions witnessed the defeat of the French Marxist party, Jules Guesde's Parti Ouvrier Francais, in trying to take over the unions and subordinate them to the party, thus emulating the German model. This was the first step in the dissociation between unions and parliamentary socialism which became so pervasive in France under the anarchists' influence in the following years.

In spite of the ideological stimulus provided by the experience, exile was hard, and Pouget remained primarily concerned with the French situation. He thus opted to return to France, even though he was certain to be jailed there and to encounter fierce repression: 'If I am not amnestied, I will do my time, and I will just be bloody unlucky if I don't pull through in the end'.43

\title{
The era of syndicalism: militant transfers and attempts at international organization
}

Pouget's stance became more decidedly internationalist after 1895, when, having returned to France, he resumed his political activities. He launched a new paper called La Sociale, which lasted until 1896, and was followed by a new series of Le Père peinard. The tone of these papers was markedly different - more strategic and far more concrete, oriented towards the great goal which Pouget now set to the French anarchists - entering the nascent trade union movement and influencing it from within. There were traditional forms of internationalism, for instance in Pouget's unrelenting support for the Spanish militants exposed to fierce government repression throughout the years 1896 and 1897 and in 1899, but even in this case, Pouget showed a great knowledge of the facts and people involved, which suggests that he received first-hand information.

It was with respect to anarcho-syndicalist propaganda that Pouget really came into his own as a transnational militant. This propaganda developed at length the British-based examples Pouget had initially used, and in his new journal, he repeatedly called for the emulation of British unions:

\begin{abstract}
As I already said, folks: let's look at what the English are doing! They are proving to us experimentally that you only need guts to hold your own against employers. Whereas in France, the socialists are wasting their forces trying to stupidly climb up the greasy pole, the English, who are a lot more practical, do not give a damn about the State, and they are marching on against the capitalists. And they're all the better for it! When will the French prols be ballsy enough to follow their example?44
\end{abstract}

What makes strikers more powerful is that they have given the boot to all politicos, and have counted on themselves only, not on the State. It is a rich lesson in initiative that the English are giving us. If only we could make the most of it! 45

The main aspects which Pouget praised - and hoped to see developed in France were trade union independence from the State, as well as militant tactics like sabotage. He praised sabotage at length in both the Peinard and La Sociale, as well as in a famous pamphlet, Le Sabotage, constantly referring to the Anglo-Saxon origins of this militant practise: 46 
I've already explained to the comrades this thing which the English practise extensively and thanks to which they are doing really well.

The motto is: a bad job for a bad pay! In England, when the boss wants to cut salaries, his prols take a look at the situation: if the strike doesn't appear as convenient, with a guaranteed victory at the end - here comes the sabotage! 47

He also contributed to the tactical transformation of the general strike in its anarchist interpretation - from a symbolical demonstration of solidarity and a rioting opportunity, to a militant practice aimed at paralyzing entire industries and marking the first step of the revolution.48 However, this was only the beginning of this process, which found its true illustration with the pre-war Great Labour Unrest, when great strikes were actually organized on an international scale.49

Pouget was in an ideal position to be carrying out this task of tactical dissemination, both through his prolific journalistic and pamphleteering output, and his influence within the CGT, as the latter became increasingly dominated by anarchist ideas. Far from remaining idle words, Pouget's injunctions became more of a reality when the CGT officially adopted sabotage as a tactic at its 1897 Toulouse congress and the French anarcho-syndicalists effectively gained control of the Confédération. Pouget was elected Deputy Secretary of the organization in 1902. Of course, the perception of the ideological meaning and international origin of sabotage at rank-and-file level remains open to debate,50 but it was nonetheless acknowledged and discussed by the leading figures of the organization, at the ideological level.

The other facet of Pouget's transnational militancy was his action towards coordinating the international syndicalist forces towards joint action and the international diffusion of revolutionary syndicalism, although it did not prove very successful - which may go some way to explain his officially poor international record. He had already attended the 1881 London Congress and the 1896 gathering of the Second International which saw the eviction of the opponents of parliamentary action - that is to say, chiefly the anarchists - all of which testified to his interest in concerted international action. Despite the disappointment and resentment caused by the political manoeuvres leading to the anarchists' expulsion, the Congress's fringe meetings were instrumental in bringing the French anarchists and anarchosyndicalists closer to their international counterparts, and especially British ones. Even before the Congress, Pouget, who was very much aware of the looming expulsion, knew that the French anarchists would have an ally in British socialists and trade unionists: 'All of them are too fond of freedom to stoop low enough to exclude anyone and play into the game of the self-seekers'.51 And indeed, once the expulsion took place, the leader of the nascent Independent Labour Party James Keir Hardie and Tom Mann, who were both parliamentarian socialists, attended some meetings to express their support of the delegates who had been expelled. The Franco-British axis was thus reinforced, although it did not materialize in any formal organization. In the aftermath of the exclusion from the Second International, Pouget attempted to coordinate antiparliamentarian forces on an international level. To this effect, he co-organized with the anarcho-syndicalist Fernand Pelloutier and the anarchist Henri Girard a Paris-based international congress for all revolutionary socialists and anarchists, scheduled to take place in 1899. However, the event was eventually banned by the French authorities. The outcomes of the 1896 and 1899 congresses thus clarify why, throughout this period, transnational networks were the privileged mode of international action for anarchists, as formal congresses and organizations offered no viable option, being either too divided to last or too vulnerable in the face of repression. Transnationalism was the product of the increasingly marginal situation of the anarchist movement in this period.

Legal hindrances could not help the progress of international action however, and in 1899, a delegation of English workers visited France. The following year, 
Pouget was part of a delegation of French trade unionists to Britain, in a gesture of solidarity meant to fight jingoism and militarism, but also in the very practical hope of setting the basis for a new trade union International through a Franco-British alliance.52 Between 1901 and 1909, he represented France at the International Secretariat of Trade Union Centres, the international federation of national trade union federations. In this position, he endlessly but pointlessly tried to stir the Secretariat in the revolutionary and practical direction of the CGT - especially against the more reformist and statist positions of the German trade unionists. He also sought to enforce discussion of antimilitarism, the general strike and the eighthour day, three watchwords which bound together the national and international levels of labour militancy. Conversely, at the 1902 congress of the CGT, he insisted on including membership of the International Secretariat in the CGT statutes.

In the same years, as the editor of La Voix du Peuple, the paper of the CGT, he did his best to advance the internationalist cause. 53

Clearly, far from the 'gniaff', the little Parisian shoemaker exclusively concerned with French problems, Pouget had a much broader scope, and a real internationalist outlook, in the sense that his vision for national emancipation was tied in with the international level. In 1906, Pouget was one of the co-drafters of the Charte d'Amiens, the CGT's manifesto of political independence, which formalized the policy pursued by the organization since the late 1890s. The document and the CGT had a great infl uence over the course of the international labour movement; the historiography of these international ramifications soon overshadowed the complex international influences received by French revolutionary syndicalism. Despite the ideological apex of the Charte, these were troubled times for the CGT and Pouget himself. The organization suffered from its lack of ideological unity, as revolutionary syndicalism remained challenged by the reformists and a revisionist wing. Low membership rates and a series of corruption scandals also belied the apparent success. The cégétistes called for the general strike on May Day, 1906, and the latter proved a failure; but in spite of this, it paved the way for increased police repression. In the aftermath of a series of violent strikes in Draveil and Villeneuve Saint Georges, along with the rest of the CGT's direction, Pouget was arrested in 1908. He withdrew from politics after his release.

In 1914, the French anarchist and syndicalist movements were torn again by the outset of the war. The ideological rift was initiated by Kropotkin, who turned his back on almost two decades of antimilitarist and pacifist propaganda, calling companions to arms in order to defend France, the cradle of the revolution, against German invasion. He was opposed by Malatesta, and a bitter debate ensued in the London-based anarchist paper Freedom. Kropotkin's call was answered by many of the anarchist-communist old guard - but among the opponents of war rallied to Malatesta were also eminent historic militants, such as Alexander Berkman, Emma Goldman, Harry Kelly, or Alexander Schapiro. They argued that there was no such thing as a defensive war. This row, which hinged on the relevance of the notion of revolutionary patriotism, lastingly redefined allegiances in the anarchist camp.

However, it is difficult to locate Pouget within this debate and thus to establish clearly his political position on the issues of nationalism and internationalism, as he did not take a stand at the time of the war. His friends and acquaintances describe him as having retired and following events from a distance.54

\section{Conclusion: Pouget's transnational record, a sign of the times}

Moira Donald, who studies the material culture of the Second International, has stressed that 'the period of the Second International should be remembered as the most successful period of international growth of socialist politics the world has ever seen - truly socialism's golden age'.55 Pouget's record as an international and 
transnational militant may seem rather poor in this light, when compared with figures like Jean Jaurès or James Keir Hardie, and their ascendancy in the international socialist movement.56 However, Pouget exemplifies another sort of transnational and international militancy - that of the revolutionary militants excluded from the Second International, who therefore found themselves forced to set up other frameworks for their international militancy and whose legacy did not take the shape of a formal organization. Their efforts at developing their own formal institutions proved fruitless, due to repression or disagreements, over the very notion of organization, or over the status of trade unions and their relationship with parliamentary politics. It is not unlikely that, because of these failures of formal organizations, for many actors of the time, international militancy was a problematic, secondary, or non-existent domain of militancy. This was compounded by the fact that French anarchism was already a very localist movement, and contributed to downplaying its international dimension, at the time and retrospectively.57 However surprising in retrospect, it is also likely that Pouget's transnational propaganda and the importance of foreign models - chiefly Britain's - in the formative years of the CGT were so obvious that they went unrecorded and were simply forgotten over time. Pouget's contemporaries thus unfailingly noted the great influence of British trade unionism over him - an aspect which is no longer acknowledged.58

In this perspective, Pouget appears as a very prolific transnational militant, who helped define French syndicalism through ideological transfers from foreign movements, and especially British trade unionism. He was a typical man of the era of the Second International, in that he understood that labour conflicts were played on an international - if not global - scale. His revolutionary syndicalism is part of a broader evolution, whereby the general strike became a practical possibility between the 1870 s and 1900 s, when the economy was sufficiently dependent on wage labour and when the workers were sufficiently organized to make it feasible. After 1905, the Russian Revolution spurred the debate on the mass strike in the European labour movement.59 It is in this broader genealogy that Pouget's reflection and militancy must be replaced. The next generation would go further in some of the directions he had opened up, calling for the establishment of international federations of industries to fight employers' international associations, or trying to organize the general strike on a truly international scale.

Pouget's career can be taken to represent the intense but unrecorded transnational activism of what could be called middling militants, combining local militancy with international organization and tactical dissemination, and uncovering the international connections of the French anarchist movement with the international labour movement, away from its traditional depiction as a picturesque emanation of the dying world of radical artisans. This shows how studying a given period or movement from the transnational angle can shed a dramatic new light on well-known periods, movements or militants.

\section{Notes}

1 João Freire, 'Influences de la Charte d'Amiens et du syndicalisme révolutionnaire sur le mouvement ouvrier au Portugal'; Eduardo Colombo, 'La FORA et la réception de la Charte d'Amiens en Argentine', Papers given at the International Conférence «1906-2006, Les 100 ans de la Charte d'Amiens», Boursedu Travail de Saint-Denis, 4-5 March 2006.

2 Notably Christian Demay de Goustine, Pouget oules matins noirs du syndicalisme (Paris: La Tête de Feuille, 1972); Xose Ulla Quiben, Émile Pouget. LaPlume rouge et noire du Père Peinard (Paris: Les Editions libertaires, 2006). An excellent biographical tribute to Pouget was written by his friend Paul Delesalle, Émile Pouget: Ad Memoriam (Paris: Publication Sociale, 1931).

3 X. Quiben, Émile Pouget, p. 7 (my translation. All passages are translated from the original French). 4 Jean Maitron, Histoire du Mouvement Anarchiste en France, 1880-1914 (Paris: Maspero, 1975),

p. 256. 
5 Stefan Berger, Keynote address, Conference on 'A World of Labour. Transnational and Comparative Histories', Coleraine University, 1-3 September 2008.

6 Constance Bantman, 'Anarchismes et anarchistes en France et en Grande-Bretagne. Echanges, représentations, transferts, 1880-1914' ( $\mathrm{PhD}$ thesis, Université Paris 13, 2007); Davide Turcato, 'Italian Anarchism as a Transnational Movement, 1885-1915', International Review of Social History, 52 (2007), 407-44.

7 Pietro Dipaola, 'Italian Anarchists in London (1870- 1914)' (PhD thesis, Goldsmiths University, 2004).

8 For instance, Carl Levy's forthcoming biography of Errico Malatesta, The Rooted Cosmopolitan: Errico Malatesta, a Life in Exile.

9 Alfred Rosmer (1883-1869) was a prominent French syndicalist in the years preceding the First World War. Christian Gras, Alfred Rosmer 1877-1964, et le mouvement révolutionnaire international (Paris: François Maspero, 1971).

10 June Hannam and Karen Hunt, Socialist Women. Britain, 1880s to 1920s (London: Routledge, 2002), p. 168.

11 Akira Iriye and Pierre-Yves Saunier, Dictionary of Transnational History (London: Palgrave, 2009). Transnational labour history was pioneered by Marcel van der Linden and Wayne Thorpe (eds), Revolutionary Syndicalism: An International Perspective (Aldershot: Scolar Press, 1990). See also Marcel van der Linden, Transnational Labour History (Aldershot: Ashgate, 2002). Recent landmarks include Benedict Anderson, Under Three Flags (London: Verso, 2005). For a brief summary of current developments regarding anarchism and syndicalism, refer to Carl Levy, 'Social Histories of Anarchism', paper given at the First Anarchist Studies Network Conference, Loughborough University, 4-6 September 2008.

12 Iriye and Saunier, Dictionary of Transnational

History.

13 Van der Linden, Transnational Labour History.

14 Peter Kropotkin (1842-1921), Russian theorist and militant who spent time in exile in Switzerland, France, and Britain and was the main exponent of anarchist communism before the First World War; Errico Malatesta (1853-1932), Italian activist who went into exile in France, Latin America, and Britain, notably promoting agitation and organization within the anarchist movement; Ferdinand Domela Nieuwenhuis (1846-1919), socialist-turned-anarchist Dutch militant who was a prolific essayist and an active militant at the international level; Christian Cornelissen (1864-1942), Dutch anarchist-communist and syndicalist, especially noteworthy for his extensive journalistic output and the outstanding liaising work he carried out through his Bulletin International du Mouvement Syndicaliste (1907-1914).

15 George Haupt, 'International Leading Groups in the Labour Movement', in Aspects of International Socialism (Cambridge: CUP, 1986), pp. 81-100; Carl Levy, 'Anarchism, Internationalism and Nationalism in Europe, 1860-1939', Australian Journal of History and Politics (2004), pp. 331-42.

16 Gustave Rousseau was a Parisian anarchist in the 1880s and his wine shop was an anarchist haunt.

The Cercle International de Paris was a local group frequented by a number of key militants in the late1880s - early 1890s, which proved important for the development of anarcho-syndicalism and the general strike in France.

17 Archives de la Préfecture de Police (APP), Paris, BA 1506, years 1888-1890.

18 Jean Grave, Le Mouvement libertaire sous la Ille République (Paris: Les Euvres Représentatives, 1930), p. 2.

19 Elisée Reclus (1930-1905) was a French geographer and one of the founding fathers of anarchist communism.

20 Père Peinard, 25 May 1890.

21 Quiben, Émile Pouget.

22 See, for instance, 'Une invasion de sauterelles humaines', Père Peinard, 28 April 1889.

23 Père Peinard, 26 October 1890.

24 Ibid.

25 Père peinard, 22 September 1889; Père Peinard, 16 June 1889.

26 The Dreyfus Affair originated in spying accusations against the French Jewish Captain Alfred Dreyfus in the 1890s, and evolved into a national row highlighting the anti-Semitism and exacerbated nationalism of a significant part of French society. The Dreyfusards were those who argued that Dreyfus was in fact innocent, and denounced the bigotry behind the accusations.

27 For instance, whilst in exile in London, another French anarchist-communist group close to Pouget published a paper satirically called Le Rothschild (June 1890-July 1891). 
28 Van der Linden, Transnational Labour History, p. 14.

29 Laurent Dornel, La France Hostile: Socio-Histoire de la Xénophobie (1870-1914) (Paris: Hachette Littératures, 2004); Gérard Noiriel, Le Creuset Français (Paris: Editions du Seuil, 1992).

30 'Les ouvriers étrangers', Père Peinard, 13 April 1890.

31 Dornel, La France Hostile.

32 APP BA 74, report dated 21 February 1886.

33 Entry of Émile Pouget in Dictionnaire Biographique du Mouvement Ouvrier Français, 1870 1914, ed. by Jean Maitron and others (Cd-rom version, Paris: Les Éditions de l'Atelier, 1997).

34 Constance Bantman, 'Internationalism without an International? Cross-Channel Anarchist Networks', Belgisch Tijdschrift voor Filologie en Geschiedenis /Revue Belge de Philologie et d'Histoire, 84, 4 (2006), 961-81; DiPaola, 'Italian Anarchists in London',

pp. 68-74; Carl Levy, 'Malatesta in London: the Era of Dynamite', in A Century of Italian Emigration to Britain 1880s-1980s. Five Essays, Supplement to The Italianist, ed. by Lucio Sponza and Arturo Tosi,

13 (1993), 25-39.

35 Père Peinard, 22 November 1889.

36 APP BA 1509 and BA 1510; Correspondence of Auguste Hamon, IISG, Amsterdam, letter from Pouget dated 15 August 1894; letter from Lucien Pissarro dated 4 December 1894.

37 'Political Fallacies', The Torch (October 1894).

38 Ibid. (June-July 1893).

39 Ibid. (May 1894).

40 Père Peinard (September 1894).

41 Ibid.

42 Père Peinard (October 1894).

43 Hamon correspondence, letter from Pouget, 4 February 1895.

44 Père Peinard, 26 July 1897.

45 Père Peinard, 19 December 1896

46 Père Peinard, 19 September 1897; É. Pouget, Le Sabotage (Paris: Marcel Rivière, 1910).

47 La Sociale, 18 April 1897.

48 É. Pataud and É. Pouget, Comment Nous Ferons la Révolution (Paris: Taillandier, 1909); Robert Brécy, La Grève générale (Paris: Études et documentation internationales, 1969).

49 The term of Great Labour Unrest refers to the wave of large-scale and usually spontaneous strikes which shook Britain between 1911 and 1913.

50 See Peter Stearns's famous attack in Revolutionary Syndicalism and French Labor: A Cause without Rebels (New Brunswick, NJ: Rutgers University Press, 1971).

51 La Sociale, 5 July 1896.

52 Susan Milner, The Dilemmas of Internationalism. French Syndicalism and the International Labour Movement, 1900-1914 (Oxford: Berg, 1990).

53 Milner, op. cit., p. 123.

54 Delesalle, op. cit.

55 Moira Donald, 'Workers of the World Unite? Exploring the Enigma of the Second International', The Mechanics of Internationalism. Culture, Society and Politics from the 1840s to the First World War, ed. by Martin H. Geyer and Johannes Paulmann (Oxford: Oxford University Press, 2001), p. 203.

56 Haupt, op. cit. Jean Jaurès (1859-1914) was the leader of the French unified socialist party and a staunch antimilitarist; he was assassinated in 1914.

57 Vivien Bouhey, 'Les Anarchistes contre la République de 1880 à 1914. Radiographie du mouvement anarchiste français' $(\mathrm{PhD}$ thesis, Université Paris $\mathrm{X}$

Nanterre, 2006).

58 Augustin Hamon, Le Molière du XXe siècle: Bernard Shaw (Paris: Figuière, 1913); Pierre Monatte as quoted in Maitron, Histoire du Mouvement Anarchiste en France, p. 256.

59 Van der Linden and Thorpe (eds), Revolutionary Syndicalism. 